\title{
БЕЗПЕРЕРВНИЙ МЕДИЧНИЙ ПРОФЕСІЙНИЙ РОЗВИТОК - НОВІ СТРАТЕГІЇ ПЕРЕДАВАННЯ ЗНАНЬ
}

\author{
О. П. Мінцер, О. В. Голяновський, С. В. Денисенко, М. В. Банчук, І. А. Ярменчук \\ Національна медична академія післядипломної освіти імені П. Л. Шупика
}

\section{CONTINUING MEDICAL PROFESSIONAL DEVELOPMENT - NEW STRATEGIES OF KNOWLEDGE TRANSFER}

\author{
O. P. Mintser, O. V. Holianovskyi, S. V. Denysenko, M. V. Banchuk, I. A. Yarmenchuk \\ National Medical Academy of Post-Graduate Education by P. L. Shupyk
}

\begin{abstract}
Найважливіша роль сучасного університету - трансфер знань. Вона покликана забезпечити передавання та трансформацію знань, досвід і навички суб'сктам навчання протягом усього життя, особливо під час безперервного професійного розвитку. Розглянуто модулі нової системи постійного навчання лікарів.
\end{abstract}

The most important function of modern university is knowledge transfer. It has been made to ensure the transmission and transformation of knowledge, experience and skills to learners through the life, especially in continuous professional development. Modules of a new system of continuous education for physicians are considered.

Вступ. Визначення сучасного суспільства як “інноваційного" відображає принципово нову його якість, що пов'язана з необхідністю максимального прискорення науково-технічного розвитку. Останній, у свою чергу, формується рівнем освітніх організацій, перш за все університетами.

Функціонування інноваційного суспільства здійснюється за рахунок інтенсивного та масштабного передавання нових знань, що генеруються в університетах, включаючи технології в різних (природничо-наукових, технічних і соціально-гуманітарних) галузях діяльності. Останнім часом для відображення подібних функцій використовується новий термін “інноваційний університет”.

Основна частина. Найважливішу роль у сучасному університеті розпочинає відігравати функція трансферу знань і технологій. Ї̈̈ значення полягає в забезпеченні постійного зв'язку між університетом $i$ замовниками фахівців - підприємствами (в даному випадку лікувально-діагностичними та профілактичними закладами, науково-дослідними інститутами).

Зрозуміло, університет не є єдиним місцем із виробництва та розповсюдження знань. Корпоративні навчальні заклади, науково-дослідні інститути також генерують знання. Проте в центрі цієї діяльності має перебувати університет як єдина організація, де здійснюється виробництво інтегрованих знань $[1,3$, 4]. Зрозуміло, що добитися ефективного та корект- ного передавання знань (трансферу знань) до сьогодні було досить важко.

Лише останнім часом з'явився інструментарій, що дозволяє вирішити проблему низьковартісного зв'язку як із суб'єктами навчання, так і з виробництвом знань. Він отримав назву "навчання на робочому місці”. У наукових дослідженнях він визначається як передавання знань на робоче місце без відриву від професійної діяльності шляхом безперервної практики та взаємодії з більш досвідченим наставником. Його розповсюдженню сприяс компетентністний підхід, який став популярним. Зрозуміло, що компетенції розвиваються не одночасно: над їх прогресом слід ретельно працювати.

Останні статистичні дані свідчать, що навчання на робочому місці та корпоративні тренінги займають лідируючі позиції середнайчастіших форматів навчання [2].

Ми запропонували використовувати для трансферу знань комплекс програмних засобів, що включають технологію Lync Server 2010. Вона надає нові можливості підключення та комунікації для суб'єктів навчання під час безперервного професійного розвитку, об'єднує й уніфікує всі сучасні засоби комунікації, а також відеоконференцзв'язок. Усі ці види комунікацій доступні через єдиний інтерфейс та єдину серверну інфраструктуру. Серед інших можливостей можна назвати інтеграцію із серверами контролю 
місця знаходження слухача. Фактичне розміщення користувача можна дослідити за адресою підмережі, до якої користувач підключений, або за найближчою точкою бездротового доступу.

Пропонується також використовувати національний продукт - ПЗ “СВIT”, розроблений Інститутом глобального інформаційного простору НАН України. Медичні та навчальні версії створювалися разом із співробітниками НМАПО імені П. Л. Шупика.

Принципово те, що нова освіта повинна базуватися на використанні декількох модулів, які віддзеркалюють функціонування комплексу систем:

1. Розповсюдження (трансферу) інформації.

2. Швидкого пошуку необхідної літератури.

3. Моніторингу навчання (портфоліо).

4. Комп'ютерного контролю знань.

5. Індивідуалізованого адаптованого навчання.

Вже перший досвід численних відеоконференцзустрічей і конференцій показав, що сьогодні технологічно можливе підключення до навчання (лекції,

\section{Лiтература}

1. Стронгин Р. Г. Университет как интегратор в обществе, основанном на знании / Р. Г. Стронгин, Г. А. Максимов, А. О. Грудзинский // Высшее образование в России. - 2006. - № 1.-C. 15-27.

2. "Группа восьми” об образовании // Высшее образование сегодня. - 2006. - № 1.-С. 15-27. семінари, консультування) тисяч тих, хто бажає отримати знання. Так, під час конференції "Багатоплодова вагітність" (Київ, 2011) нами було забезпечено вільне приєднання понад 1000 фахівців з України та зарубіжжя. Були задіяні 92 точки з'єднання is 75 міст України. Підкреслимо, що подібне з'єднання не потребує ніякого спеціального обладнання для користувача.

По суті, відкривається нова ера передавання професійних медичних знань і нової організації безперервного професійного розвитку лікарів та провізорів.

Висновки: 1. Сучасний трансфер знань відображає систему організації багатоканального та багаторівневого інтерфейсу між університетом і його зовнішнім оточенням, передусім суб' єктами навчання та підприємствами з високими технологіями.

2. Ефективний безперервний професійний розвиток лікарів і провізорів неможливий без впровадження інформаційних технологій, зокрема навчання на робочому місці.

3. Всемирная конференция по высшему образованию 2009. Итоговое коммюнике // Высшее образование сегодня. -2009 . - № 8. - С. 13-17.

4. Грудзинский А. О. Трансфер знаний - функция инновационного университета / А. О. Грудзинский, А. Б. Бедный // Высшее образование в России. - 2009. - № 9. - С. 66-71. 